\title{
Development as Obligation and the Obligation of Development: A Philosophical Reflection on the Nation State in Africa
}

\author{
Rev. Fr. Dr. Gregory Ogbenika \& \\ Paul Michael Kehinde \\ http://dx.doi.org//10.4314/ujah.v17i 2.8
}

\begin{abstract}
The problem of the relevance of African philosophy to development in Africa arises from the fact that the modern African philosopher faces problems from within and outside his discipline. Specifically how do we build up a social order that can effectively confront Africa's existential challenges.? How does development become an obligation to the Africans to necessarily carry out? How do we define our obligation of, to, development, given the numerous challenges facing our peoples? This situation is challenging because an inherited foreign colonial legacy obstructs efforts to install primary and prioritized endogenous perspectives for solutions to African problems. The dualistic roles of philosophy both as an academic field and as a thought system generates a crisis of values in African development concerns that we are compelled to tackle by using both the strategies of physical development and moral values for a man centered development.
\end{abstract}

\section{Introduction}

We are interested in the relevance of African philosophy to the development question and discourse in Africa. African philosophy now has some bearing on the contemporary matters of philosophical interest to the Africans. What does philosophical knowledge do for people in other parts of the world? What should philosophical knowledge do for the Africans? The modern African philosopher is faced with all sorts of problems arising from 
within and outside his discipline. African philosophy becomes intricately linked with cultural emancipation and survival and thereby fashions its methods to confront Africa's existential challenges. Ogbogbo (1997: 39) insists that "this challenge betrayed the poverty of African philosophy as it became increasingly obvious that African philosophers could not use their disciplines to tackle Africa's myriad problems."

What is the relevance of African philosophy to the African life? What are the reasons for doing African philosophy? An author seems to speak the mind of many philosophers when he says that "it can now be said with a certain degree of confidence that African philosophy has come along way from the early days when questions of methodology and pedigree were the overwhelming concern" (Garuba 2003:59). Oguejiofor (2001:13) pushes the argument that "those who are engaged in philosophical inquiry in the African continent should review the relevance of their pursuit to a continent bedeviled by apparently endless and intractable problems." In fact Hountondji (1983:143) insists that the issue is "not the adoption of an attitude of indifference to African problems but rather the proper framing of African problems which cannot always or necessarily be problems relative to Africa." Indeed Irele (1986: 122) is blunt when he says that "the set of problems perceived by an earlier generation of African and black intellectuals is now being supplanted by a new set of problems raised by the younger generation."

\section{Situating the Quest for Development as an Obligation of the African Philosophical Tradition(s)}

The well being of the human person, according to Wiredu, is the singular task of development. In the continent of Africa, situational shortfalls clearly precipitate into the present crisis of development in Africa. The traditional attempt to conceive development sees it in terms of the technological, economical or political. Iconic 
scholars such as Kwasi Wiredu (Wiredu in Oladipo 2000:121) would argue that the notion of development is material and moral. While the material dimension of development involves the careful application of the dividends of science and technology to exploit and control the physical environment, the moral aspect of development is made up of the consistent endeavour in regulating, as well as improving human relationships via the promotion of equality and mutual cooperation. (Igbafen 2003:2-3).

Scholars may wish to show the relevance of philosophy to African socio-cultural existence. That is, these writers want to use philosophy to make impact on the lives of Africans. For example, scholars may use philosophy to solve, or at least address some of the pressing problems besetting the African societies as it were. As Ogbogbo (1997: 35-36) argues "the crisis of development that confronts Africa has increasingly brought to the fore the role of African universities as agents of development. For the various disciplines it has become justify your relevance or perish. African philosophy happens to be one of such disciplines that are affected by this quest for relevance." The modernists argued mainly that African philosophy should have a contemporary focus that takes into consideration current issues and adoption of foreign values, affecting the lives of Africans. Such scholars included, Kwasi Wiredu, Henry Odera Oruka, Peter Bodunrin, Godwin Sogolo, and many others. Even though they rejected some of the claims made by the traditionalists who called for the adoption of some elements of the traditional African past, yet, the modernists themselves did not agree on what should constitute contemporary African philosophy and how it should be done. Most of them held various positions about the nature of the modernist school of thought. They examined issues concerning the model of philosophy to be adopted by the Africans, the 
concepts of truth, person and the State, the role of culture, language and science in African development, uses of endogenous knowledge in Africa, and the idea of society and democracy to be adopted for African development, among others. Let us examine a few of these concerns and how they connect to concerns about African development within the academic system of the University.

For the Africans "the post-World war 11 period coincides with the beginning of access to university and college education by a greater number of African people, one observes the concurrence of the establishment of academic departments of philosophy in African universities" (Masolo 1997: 63). Okolo (1992:192) insists that "philosophy as a professional or academic activity is certainly a late comer in Africa and among African academics." Despite this "university trained African philosophers are satisfied that since independence, they have been able to establish philosophy as a discipline in black Africa" (Mafeje 1991:3). Given that philosophy as a strictly professional or academic activity is certainly a late comer in Africa and among African academics and universities (Masolo, 1997:63, Bodunrin, 1992:16, Okolo, 1992:192-195), it can be said that "the professional philosopher in modern Africa is in a dilemma arising from inherited professional handicap due mainly to historical antecedents, as well as the pressure to respond to the growing demand for utility" (Sogolo, 1990:39-40). This is not all. Worse forms of the dilemma arise out of self-inflicted problems and lapses in the construction of the theoretical and practical trajectories of the philosophical discipline in Africa. Thus there are visible lapses in the areas of imaginative expansion of the frontiers of the field, and in the areas of the theoretical capacity for problem solving. Mafeje (1991:11) holds that "the continued intellectual domination Africa by foreigners in research and in development policy formulation 
(can be) seen as a sign of failure on the part of African intellectuals to stake their claim and develop endogenous theoretical perspectives and, thus put themselves in a position where they could provide new solutions to African problems."

\section{Conceptualizing the Theory and Knowledge of Obligation}

The concept of obligation is captured in ethical theories which have developed over time. The concept "ethics" is derived from the Greek word ethos which means character. According to Socrates, ethics is the knowledge of good and evil; the knowledge of the wisdom of life. Ethics is a sub-branch of philosophy and precisely a direct branch of axiology that deals with how human beings ought to behave. Ethics may be defined as fundamental norms of human conduct. The purpose of ethics is to influence human attitude. The focus of ethics is morality. Morality comes from the Latin word moralis, meaning customs or manners. Ethics or moral philosophy presupposes freedom; freedom involves choice and responsibility. Ethics is the practical science which aims at procuring man's unqualified good; his absolute good. Ethics teaches not only the most general rules of remote application but also the particular rules applicable to the particular action to be performed. Thiroux (2001) says ethics asks such questions as: What part does self-interest or the interests of others play in the making of moral decisions and judgments (Thiroux, 2001:1-2)? In the context of the focus of this essay, let us define ethics as the evaluation and analysis of human conduct in relations to what he expects from other people and what other people expect from him. Although this narrow definition of ethics must be understood as only including relationships among human beings and excluding other non-human element in nature. From our definitions especially the last definition, we are correct to say that the focus of ethics is obligation. There are ethical theories which 
philosophers use as tools in analyzing and engaging ethical discourses. Michael (2005) opined that ethical theories can be separated into two main categories: one category includes theories of the good the other category includes theories of the right. The distinction between these two categories is that theories of the good attempt to explain what is worthwhile in life such as beauty or human happiness, while theories of the right explain what a morally correct course of action is such as lying or stealing. Theories of the right, as opposed to the good, describe actions that should be taken that are in accordance to a general rule. There are two major categories of these types of theories: teleological and deontological. Teleological theories apply a general rule that should be followed to all possible courses of action and determine morality based on the end result of that action. However, under a teleological theory, one action could be considered moral and immoral at different times under different circumstances. For example, lying may be justifiable and the right thing to do under certain circumstances, and morally bad in other circumstances. Most teleological theories are considered consequentialist. Conversely, deontological theories describe actions which are always good or always bad; they usually construct a set of rules for morally right and morally wrong courses of action. Deontological theories judge actions based on the means, not on the ends. Some examples of teleological theories are ethical hedonism, utilitarianism, virtue, and welfarism, each of which apply a different rule to certain actions. Examples of deontological theories include universalized duty, rights, theism, and existentialist subjectivism (Michael, 2005:5-9). Obligation is thus, fundamentally an ethical concept that is applicable to other field of human endeavour such as law and politics.

The concept of obligation must be understood properly to enable us narrow it down to political obligation which is the 
focus here and then examine its problems. What then is obligation? An obligation is a responsibility; that is, a duty. One's duty is an action that a person is obliged or mandated to perform. Obligation represents a sense of duty, responsibility and commitment which can further be explained as having a stake in something and having a feeling of belongingness. Another way to understand the concept of obligation is to construe it within the framework of the idea of reciprocity. In that case, obligation can be defined as the reciprocity of duties, responsibilities and commitment between persons, groups, associations, and in the context of our discussion, between the state and its citizens. There are different kinds of obligation: one is duty of perfect obligation and the other is duty of imperfect obligation. The former has an "a priori" nature; one that can be exerted from an individual by necessity or compulsion while the latter is based on the individual's choice or volition.

Some Ancient and Modern Theories of Political Obligation in the History of Philosophy: Plato, Aristotle, Hobbes And Locke.

The different theories of the State espoused by political thinkers over the centuries have as there central concern the question of political obligation. Socrates' political and moral obligation was seem in his readiness to accept the death verdict passed on him by the Athenian State on the ground that; he had enjoyed the State's security and protection all his life and that it would be unjust for him not to accept its judgments (Melchert 1991:67-81). The implication of Socrates concept of political obligation is that the protection of life and property, and the provision of social basic amenities for the citizens are the justification for political obligation. But Socrates concept of political obligation raises a serious question which is; should the state do injustice to its citizens just because it provides security and social amenities? 
Does an individual's political obligation include losing his or her life, freedom and dignity unjustly? Another conception of political obligation is the one identifiable in Plato's concept of the State.

Plato in his Magnum Opus the "Republic" proposed a utopian concept of the State. In his view, an individual's political obligation to the State is anchored on giving the individual his due. Put differently, an individual is obliged to obey the State in so far as the State provides for him a structure, system or framework within which his due is equitably given. Plato built his whole architecture of the State on justice and was showing how a State should be organized. In his view a just society is one in which the natural make-up and ability of the individual can be explored for the ultimate good of all (Plato The Republic 1999). In this sense, an individual is obliged to obey the State on the grounds that the State will give him or her required privileges, rights and opportunities to function as a human being within the State. It also include that the individual will benefit from the State in terms of social amenities. Whereas Plato was utopian in his conception of the State, Aristotle was rather naturalistic. As a naturalist, his political philosophy is hinged on his political naturalism and so is his political obligation. For Aristotle the State exists by nature and two interpretations are obtainable: internal cause and teleological cause. The internal cause explanation says that a thing is natural if and only if, it has a nature in the sense of a source or cause of moving or being at rest. What Aristotle is saying is that the State generated internally from the smallest unit of the society namely the family and then community and then the town and then the State. Teleologically, Aristotle conceives of the State as a natural entity arising among persons to serve a natural function such as: the provision of the common defence; the promoting of trade; and most importantly the State of the 
Politics also has "eudaimonia" as the goal of its citizens (Miller 1997:37). For Aristotle therefore, political obligation is thus tied to the naturalness of the State. What this means is that a person is obliged to obey the State just because it exists naturally in the teleological and internal cause sense. Again, the question of political obligation arises in Aristotle's concept of the State as he merely assumes that man naturally has the tendency to obey rules and laws of the State, given that he is a social animal. The implication of this is that Aristotle built his political obligation on human nature and assumes that the human nature is completely positive. But is it the case that human nature is completely positive? Where is the place of element such as greed, ego, and self-centeredness among other things in man? The inadequacy of Aristotle's conception of the State leads us to the contractarians especially - Hobbes and Locke.

In the view of the Contractarians (Hobbes and Locke), I ought to obey the State because I have somehow promised or undertaken to do so. This explanation suggests that many obligations arise from something that has happened in the past, from a positive undertaken. The important question here is this: is it the case that the commitment or agreement from which my obligation arises is arbitrary or unconditional? Since the commitment is entered into for the sake of some ultimate end, for example; security and adjudication in Hobbes' version, the protection of natural rights in Locke's, its binding force is therefore conditional on the effectiveness of the State in realizing the end in question (Hobbes 1963:139-168) and (Locke 1963:169-204). For this reason, the contract theory can never be absolutist and thus does not provide sufficient justification for political obligation. The urgent quest to answer the question arising from the problem of political obligation takes us to another concern in Aristotle idea of the State which is the nature - craft dichotomy. The 
purpose is to help us adequately answer the question of political obligation in a State like Nigeria. What exactly is Aristotle's nature - craft dichotomy and how does it reflect a society's creation story or origin?

\section{Development as Obligation or the Obligation of Development in an African Experience}

To understand the ways by which development can be seen as an obligation or the ways that we can have an obligation to development, there is a need to do a clarification of the three domains of obligation, namely, legal, moral and political. Let us start with the legal aspect. A legal obligation is a bond between two legal persons which confers enforceable rights and duties. For example, if $\mathrm{X}$ negligently injures $\mathrm{Y}$, then this confers on $\mathrm{X}$ the obligation in law to make due compensation to $\mathrm{Y}$, and $\mathrm{Y}$ has a right to that compensation (Scruton, 1982:330). The weakness of the legal obligation is that it failed to take into consideration cases where lawfully keeping to a legal bond can cause greater harm. For example if there was a bond between $\mathrm{X}$ and $\mathrm{Y}$ that $\mathrm{X}$ should take custody of a weapon belonging to $\mathrm{Y}$ as $\mathrm{Y}$ is away for a short time, should $X$ be law bound to return the weapon to $\mathrm{Y}$ on arrival even when $\mathrm{X}$ notices that $\mathrm{Y}$ is insane. Will it not be better for $X$ to break the bond rather than allow $\mathrm{Y}$ cause harm to $\mathrm{X}$ and other people? I think the good of $\mathrm{X}$ and other people are more important than that of Y. Legal obligation seems to be derived from moral obligation, hence the next line of attention. Legal obligation should therefore be understood as a legal bond between at least two persons and a forceful authority enabling the implementation of the obligation

The term moral obligation has a number of meanings in moral philosophy, in religion, *and in layman's terms. Generally speaking, when someone says of an act that it is a 
"moral obligation," they refer to a belief that the act is one prescribed by their set of values. A moral obligation is a responsibility imposed on the moral agent by his own reason. To declare an action a moral obligation is to say that they are actions that others can legitimately insist that we perform while our expectations are those actions that we can legitimately insist that others perform. Moral obligation a duty which one owes, and which he ought to perform, but which he is not legally bound to fulfil. These obligations are of two kinds: one is those founded on a natural right; as, the obligation to be charitable, which can never be enforced by law: two is those which are supported by a good or valuable antecedent consideration. Mill (1990:468) asserts that duty is a thing which may be exacted from a person as one exacts a debt. Real duties are duties of perfect obligation which ensures that a correlative right resides in some person. As Kant also insists "duty is the designation of any action to which anyone is bound by an obligation" (Kant 1990:391). Moral obligations make sense to us given that human beings are "entities capable of long range action, of responsibility, of deep relations with other people" (McShea 1979:394).

Political Obligation is one, if not the basic and fundamental question and problem in political philosophy. The problem stays open, and it is a problem which has exercised moral and political thinkers all through the ages. Political obligation is distinct from other forms of obligation because it raises serious questions which are both legal and moral at the same time. Such questions for example include: What is the foundation of authority? Why should laws be obeyed? Why should I obey the State? Political obligation therefore raises a serious problem which consists in the justification of obedience to the State. The study of the problem of political obligation is important because it has been discovered that people obey the State when they are 
restrained by the fear of probable consequences of disobedience or by the conviction that they are morally obliged to do so. More generally, the problem of political obligation is concerned with the theories of the State, its foundation or what puts the State in the position to demand obedience from the individual or its citizen. Again the problem consists in providing justification for the demand for obedience by the State vis-à-vis the responsibility of the State to its citizens. The problem of Political obligation as a major concern in the history of political philosophy can be located in the different theories of some political thinkers.

The point we are making is that the quest for, and pursuit of development in Africa needs to be viewed as a duty of perfect obligation by all the key stakeholders such as the government, civil society and agencies. Their actions require a larger dose of legal and social responsibility to the members of the society and to the less privileged and vulnerable members of the society. At the heart of development as an obligation is the pursuit of mechanisms for peace and social justice, such as the parameters of the fair treatment of others, the respect for human rights and obedience to the rule of law by all actors, as expressed variously in the ordinances of the society under different circumstances.

The truth is that an obligation to development requires a new set of human and humane values that will include civility, a more rational and scientific outlook to life and a more enlightened perspective to issues that involve the use of non-violence, logical arguments, the role of education and public awareness as standards for creating social opportunities and prospects for human progress within a stable and viable social and political arrangement. 


\title{
Conclusion
}

We discussed the problem of the relevance of African philosophy to development in Africa. This issue arose from the fact that the modern Africans faced problems and difficulties from within and outside his environment. We posed and attempted to answer the question of: if it was expedient that we built our social tradition on paradigms or categories that effectively confronted Africa's existential challenges. We situated the broader imperatives of cultural emancipation that were placed side by side with technical concerns about the theory and praxis of interfacing academics with real life in various parts of the continent. This situation of the nexus between the imperatives of culture and professionalism challenged our modern struggle to escape a foreign colonial legacy. We sought ways to install endogenous perspectives for solutions to African problems. We were compelled to tackle this problem using both the strategies of physical development and moral values for a man centered development.

\author{
Rev. Fr. Dr. Gregory Ogbenika \\ Philosophy Department, \\ Major Seminary of All Saints Ughielle, Ekpoma, Nigeria \\ $\&$ \\ Paul Michael Kehinde \\ Program Officer, Educational Counselling and Literacy \\ Organization (ECLO), Benin, Nigeria
}




\section{References}

Bodunrin, Peter. (1992) 'Philosophy in Africa-The challenge of relevance and commitment' in Herta. N. Docekal et al edited. Postkoloniales Philosophieren Africa. (R.Oldenbourg. Verlag Wiem Munchen). Pp. 15-39.

Garuba Harry (2003) "Barry Hallen. The good, the bad and the beautiful: Discourse about values in Yourba culture" Philosophia Africana. Vol.6. no.1. March. Pp.59-62.

Hobbes T. 1963. Leviathan in Somerville and Santoni (ed). Social and Political Philosophy Reading From Plato to Gandhi. New York: Doubleday. Pp. 139-168.

Hountondji Paulin (1983) "Distances" Ibadan Journal of Humanistic studies. No.3. October. Pp.135-146.

Igbafen M.L. (2003) Basic Issues and Theories in Philosophy of Development. (Ekpoma: A. Inno Printing Press.

Irele Abiola (1986) "Contemporary thought in French speaking Africa" in I. J. Mowoe and R. Bjornson edited. The Legacies of Empire. New York: Greenwoods. Pp. 121-158.

Kant, Immanuel (1990) The Science of Right trans Hastie Great Books of the Western World vol. 39 (edited) Alder M. J. Chicago Encyclopedia Britannica Inc)

Locke J. 1963. Leviathan in Somerville and Santoni (ed). Social and Political Philosophy Reading From Plato to Gandhi. New York: Doubleday. Pp. 169-204 
Mafeje, Archie. (1991) African Philosophical Projections and Prospects for the Indigenisation of Political and Intellectual Discourse. Harare: Sapes.

Masolo, Dismas. (1997) "African Philosophy: A historical overview." In Eliot Deutsch \& Ron Bontekoe (edited) A Companion to World Philosophies. (Massachusetts: Blackwell) pp. 63-77.

McShea Robert J., 1979, "Human nature ethical theory" Philosophy and Phenomenological Research. Vol. Xxxix. No.3. (March). pp. 387-401.

Melchert N. 1991. The Great Conversation A Historical Introduction to Philosophy. California: Mayfield Publishing Company. pp. 67-81

Mill, J.S (1990) On Liberty Representative Government Utilitarianism Great Books of The Western World, Vol. 40 (Edited) M.J Alder (Chicago: Encyclopedia Britannica Inc).

Miller F.D. 1997. Nature, Justice and Rights in Aristotle's Politics. Oxford: Oxford University Press. P. 37 -40.

Ogbogbo C. B.N. (1997) "The poverty of African philosophy" Ibadan Journal of Humanistic studies. No.7. October. Pp.35-42.

Oguejiofor, Obi. J, (2001) Philosophy and the African Predicament. Ibadan: Hope Publications.

Okolo, Chukwudum. B. (1992) "Philosophy in Africa. Present and future" Nagl-Docekal H. Heinrich, R., Nagl, L., and Vetter, H. Postkoloniales philosophieren Afrika. (R. Oldenbourg, Verlag Wien Munchen). Pp. 190-203. 
Oladipo, Olusegun. (1998) The idea of African philosophy. Ibadan: Hope publications.

Oladipo, Olusegun. (2000) "Nigeria in the Twenty-First Century, Challenges of Freedom and Development" in Olusegun Oladipo edited Recall. Ibadan: Hope Publications.

Plato The Republic .1999. Benjamin Jowett (Translated) New York: Banes \& Nobles Books

Scruton, R. (1982) A Dictionary of Political Thought. New York: Hill and Wang. Pp. 330.

Sogolo, Godwin. (1990) "Options in African Philosophy" Philosophy. Vol. 65. pp. 39-52.

Thiroux, J.P. (2001) Ethics Theory and Practice, Seventh Edition. New Jersey: Prentice-Hall, Inc., p. 1-2. 